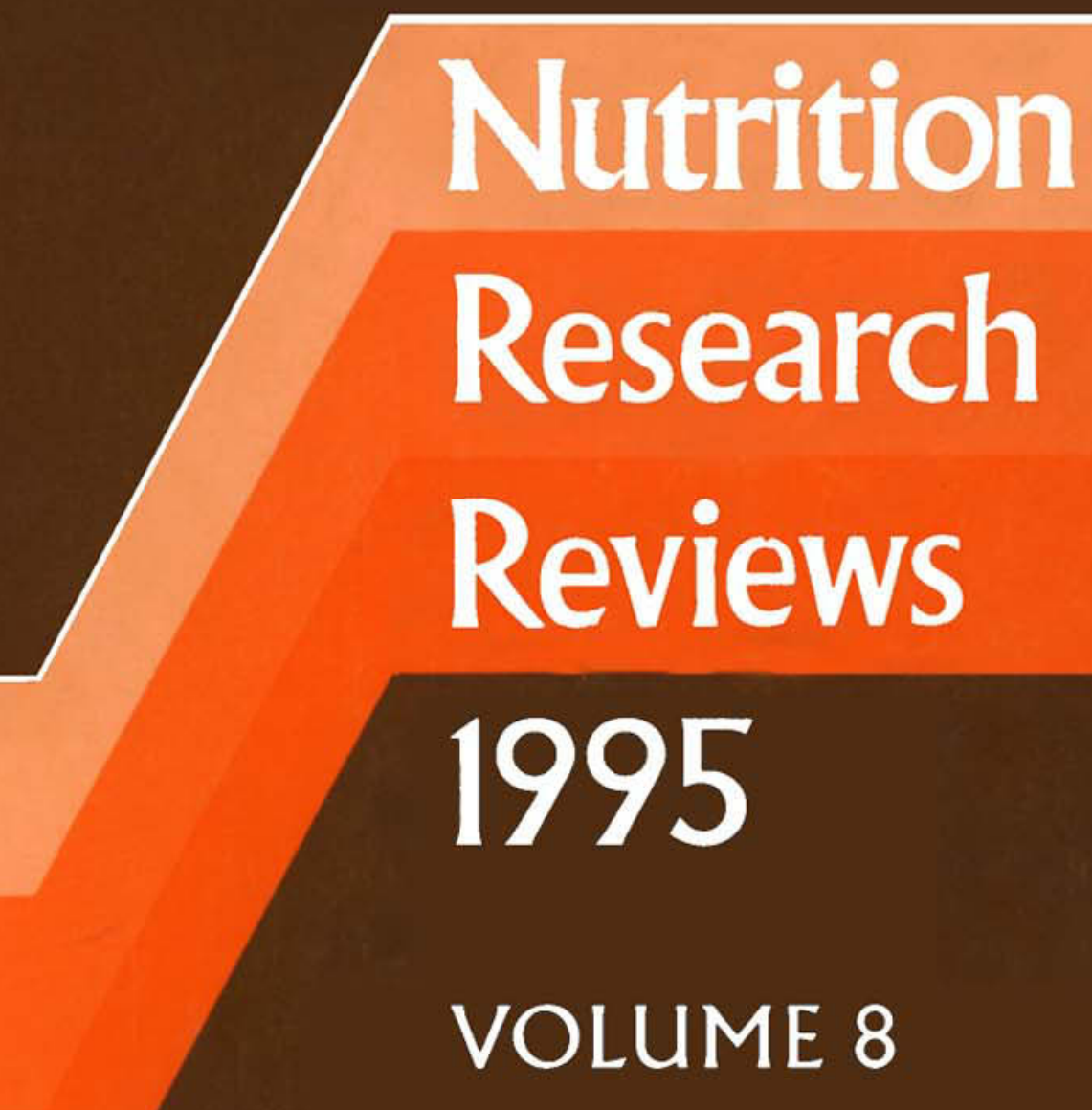

\title{
VOLUME 8
}




\section{EDITORS}
J. W. T. Dickerson
J. M. Forbes
M. 1. Gurr
D. J. Millward

\section{INTERNATIONAL EDITORS}

\author{
L. H. Allen (USA) \\ J. Black (Australia) \\ L. Hambraeus (Sweden) \\ J. Okumura (Japan) \\ N. W. Solomons (Guatemala)
}

Nutrition Research Reviews is published annually by Cambridge University Press for the Nutrition Society which owns it and controls its publication. Information about the Nutrition Society, which has as its object the advancement of the scientific study of nutrition and its application to the maintenance of human and animal health, may be obtained from the Honorary Secretary, Dr J. C. Mathers, The Nutrition Society, 10 Cambridge Court, 210 Shepherds Bush Road, London, W6 7NJ, U.K. Cambridge University Press also publishes the British Journal of Nutrition and the Proceedings of the Nutrition Society for the Society.

Nutrition Research Reviews (0954-4224) may be purchased separately from booksellers or directly from Cambridge University Press. The subscription including postage (excluding VAT) to volume 8, 1995, is $£ 49$ payable in advance to Cambridge University Press, The Edinburgh Building, Shaftésbury Road, Cambridge CB2 2RU. The subscription in the USA, Canada and Mexico is US\$89, and inquiries there should be addressed to Cambridge University Press, Journals Department, 40 West 20th Street, New York, NY 10011-4211. All orders must be accompanied by payment. EU subscribers (outside the UK) who are not registered for VAT should add VAT at their country's rate. VAT registered subscribers should provide their VAT registration number. Japanese prices for institutions (including ASP delivery) are available from Kinokuniya Company Ltd, P.O. Box 55, Chitose, Tokyo 156, Japan.

Copying. This journal is registered with the Copyright Clearance Center, 222 Rosewood Drive, Danvers, MA 01923. Organizations in the USA who are registered with the C.C.C. may therefore copy material (beyond the limits permitted by sections 107 and 108 of the US copyright law) subject to payment to C.C.C. of the per-copy fee of $\$ 11.00$. This consent does not extend to multiple copying for promotional or commercial purposes. Code $0954-4224 / 95 \$ 11.00+10$. Organizations authorized by the Copyright Licensing Agency may also copy material subject to the usual conditions.

ISI Tear Sheet Service, 3501 Market Street, Philadelphia, Pennsylvania 19104, USA, is authorized to supply single copies of separate articles for private use only.

For all other use, permission should be sought from the Cambridge or New York offices of Cambridge University Press.

\section{Future issues}

Recommendations for topics and authors in any field of nutritional research are invited. Recommendations should be reasonably precise and must be accompanied by a clear statement on why the proposer thinks that a review of the chosen subject would be particularly timely and why the particular author or group of authors is being proposed. We hope to give as much prominence to authors from overseas, as long as they write well in English, as to those from the United Kingdom. Proposals, all of which will be considered carefully, should be sent to: Professor M. I. Gurr, Vale View Cottage, Maypole, St Mary's, Isles of Scilly, TR21 0NU, United Kingdom. Proposals for Volume 10 (1997) should be sent to arrive by June 1996. 